\title{
ON SOME OF THE AFRICAN LONGICORNS DESCRIBED BY HOPE AND WESTWOOD.
}

By K. JORDAN, РH.D.

PRori ROFESSOR E. B. POULTON kindly lent me the African Longicorns of the Hope Department for some time, so that I was enabled to compare them with the specimens in the collection of the Tring Museum and take notes on the types contained among the material of the Hope Department. I find that some of Hope's species have been wrongly identified by subseqnent anthors, myself included. It is especially his paper in Ann. Nat. Hist. 1843, p. 366, "On some New Insects from Western Africa," which has given rise to much uncertainty, owing partly to the shortness of the descriptions and partly to the erroneous place assigned to some of the insects. The following list gives all the Longicorns named in that paper.

\section{Stenodontes downesi.}

Mallodon downesii Hope, l.c. p. 366. n. 47 (1843) (Fernando Po ; Cape Palmas).

The well-known common Prionid. Hope mentions Mallodon picipennis and raddoni as being taken at Sierra Leone; these are nomina in coll. of specimens of downesi, which varies a good deal.

\section{Acanthophorus palini.}

Acanthophorus palinii Hope, l.c. no. 48 (1843) (Sierra Leone).

This is the insect which Waterhouse figures in Aid to the Identification of Insects, p. 25, t. 167, fig. 1 (1888?).

\section{Acanthophorus longipennis.}

Acanthophorus longipennis Hope, l.c. no. 49 (1843) (Sierra Leone).

Acanthophorus megalops White, Cat. Brit. Mus. vii. p. 15 (1853) (Fernando Po).

Lameere, Ann. Mus. Congo, Zool. iii. Longic. (1903), treats the name as a synonym of yolofus Dalm. (1817). The type-specimen of the name (nymotype), however, which is a female, is very near to megalops White (1853), and in my opinion the same species. The puncturation is much more dispersed than in other Acanthophorus; the femora are quite smooth; the tibiae bear only scattered punctures and, in the lateral depression, a few setiferous granules. The apex is dorsally emarginate in all the tibiae, each angle of the sinus being produced into a tooth nearly as in $A$. palini. The antennal segments are not channelled.

\section{Phyllarthrius africanus.}

Phyllarthrius africanus Hope, l.c. no. 50 (1843) (Sierra Leone).

The antenna is described as having only ten segments. What Hope called the second segment is really the third, the second being quite short. The pronotum has a depression on each side, much as in Ptycholaemus. The elytra are cylindrical, nearly as in Purpuricenus, the apical margin of each heing rounded. The black apical area of the elytra measures about $2 \mathrm{~mm}$. 
We have a female from Benito, Portnguese Cameroons, which agrees with the nymotype of africanus, but the apical area of the elytra is twice the size (about $4 \frac{1}{2} \mathrm{~mm}$.) and the lobes of the antennal segments are narrower. I name this form

\section{P. africanus benitensis subsp. nov.}

\section{Phyllarthrius unicolor.}

Phyllarthrius unicolor Hope, l.c. p. 367. no. 51 (1843) (Ashanti).

I have not seen a second specimen of this species.

\section{Phycholaemus signaticollis.}

Hamaticherus signaticollis Hope, l.c. no. 52 (1843) (Cape Palmas).

Phycholaemus troberti Chevrolat, Ann. Soc. Ent. France p. 324. no. 5 (1858) (Guinea).

This species is the same as troberti Chevr.

\section{Plocederus viridipennis.}

Hamaticherus viridipennis Hope, l.c. no. 53 (1843) (Sierra Leone).

Antenna and legs yellowish tawny. Prothorax as in P. chloropterus, the transverse folds not quite so regular, the spine pointed. Elytra tawny, but this colour almost entirely suppressed by a blue-green gloss; puncturation more minute than in chloropterus; sutural angle with a short tooth, onter angle with a longer one. Abdomen tawny ochraceous.

\section{Domitia pilosicollis.}

Hamaticherus pilosicollis Hope, l.c. no. 54 (1843) (Cape Palmas).

This is not a Cerambycid, but a Lamiid. It belongs to Domitia, which is nearly allied to Monochamus, and is very near to D. aenea Parry (1849), the type of which I have not compared. D. aenea stands under Sternotomis in the Munich Catalogue.

\section{Plocederus glabricollis.}

Hamaticherus glabricollis Hope, l.c. no. 55 (1843) (Cape Palmas).

Legs and the first segment of the antenna tawny red, rest of antenna blackish tawny; knees black. Thorax smooth on disc, with some minute punctures and posteriorly two callosities; no spine on the side, but three callosities. Elytra green; puncturation minute and sparse; sutural angle with acute spine, outer angle pointed, but very little produced.

\section{Ionthodes amabilis.}

Ionthodes amabilis Hope, l.c. no. 56 (1843) (Sierra Leone).

The type-specimen seems to be somewhat discoloured. The elytra are blue with a velvety streak along the centre of each. The spots of the prothorax are white, while they are yellowish in our specimens from Sierra Leone.

\section{Callichroma afrum.}

Callichroma assimile Hope, l.c. no. 57 (1843) (Sierra Leone).

I consider this to be the same as C. afrum L. (1771). 


\section{Mecaspis laetum.}

Callichroma laetum Hope, l.c. p. 368. no. 58 (1843) (Cape Palmas).

Greenish blue, or blue; antenna and legs black. No velvety pubescence on pronotum and elytra. M. dives Pascoe, Tr. Ent. Soc. Lond. p. 495 (1888), from Delagoa Bay, seems to be the same.

\section{Mecaspis atripenne.}

Callichroma atripenue Hope, l.c. no. 59 (1843) (Sierra Leone).

This is a well-known species, which cannot be confounded with any other Mecaspis.

\section{Callichroma igneicolle.}

Callichroma igneicolle Hope, l.c. no. 60 (1843) (Ashanti).

Callichroma imitator Jordan, Nov. Zool. i. p. 168. no. 86 (1894) (Gold Coast).

My imitator is the same as igneicolle. There are in collections several similar forms which have received names. They differ slightly from igneicolle, especially in the plication of the pronotum. Their distinctness is doubtful.

\section{0xyprosopus speciosus.}

Cerambyx speciosus Dalman, in Schoenh., Syn. Ins. i. 3. App. p. 153. no. 210 (1817) (Sierra Leone). Promeces carbonarius Hope, l.c. no. 61 (1843) (Sierra Leone).

Blnish black, legs yellowish tawny. The only Oxyprosopus of this colour known to me.

\section{Euporus amabilis.}

Euporus amabilis Hope, l.c. no. 62 (1843) (Cape Palmas).

Anterior half of pronotum purplish blne like the occiput, without any punctures; disc of the dilated central part of the prothorax densely punctured, the puncturation more dispersed on the sides. Shoulders smooth, glossy, but the area between the shoulder and the scutellum as densely rugate as the rest of the elytrum.

\section{Euporus strangulatus.}

Euporus strangulatus Serville, A un. Soc. Ent. France, p. 21 (1834) (East Indies ?). Rhopalophora? resplendens Newman, Ent. Mag. v. p. 496 (1838) (Fernando Po).

Euporus chrysocollis Hope, l.c. no. 63 (1843) (Fernando Po).

The puncturation of the thorax is very coarse; the anterior half of the pronotum is not quite smooth, there being some large punctures in the depression; the punctures on the disc of the wider part of the prothorax are centrally less numerous than at each side of the middle line, the s smooth area penetrates mesially into the patch of punctures. There occurs a similar species in the same districts which has a broader prothorax, with the centre of the wider portion very densely punctured.

\section{Sternotomis principalis.}

Lamia principalis Dalman, in Schoenh., Syn. Ins. i. 3. App. p. 162. no. 223 (1817) (Sierra Leone). Sternodonta palini Hope, l.c. no. 64 (1843) (Sierra Leone).

In this form the spots in the posterior half of the elytra are green. We have several specimens from Sierra Leone. The individuals from Angola have all the 
markings of the elytra buffish ochraceons; the pubescence between these markings is duller green than in the principalis principalis. This Angola form may be called

St. principalis hilaris subsp. nov.

\section{Prosopocera princeps.}

Sternodonta princeps Hope, l.c. p. 369, no. 65 (1843) (Ashanti).

Lamia (Sternotomis?) princeps, Westwood, Arc. Ent. ii. p. 125. t. 78. fig. 2 (1845) ; id., l.c. p. 147 (1845).

A very distinct species, easily recognised by the pattern of the elytra.

\section{Sternotomis mirabilis forma amabilis.}

Sternodonta amabilis Hope, l.c, no. 66 (1843) (Ashanti).

Sternotomis submaculata Kolbe, Ent. Zeit. Stett. p. 65. n. 31 (1893) (Togoland; Ashanti) (1801).

Drury's St. mirabilis is dichromatic, nymotypical mirabilis being the green form and amabilis the tawny one.

The base of the pronotnm in amabilis is green, as in S. imperialis F.; the elytra bear a green sutural spot as in S. chrysopras, but the suture is more or less extended green also in front of and behind this spot; sometimes the ochraceous markings are separated by more or less green interspaces. The structure by which the species can be most easily recognised is the basal tooth of the mandible of the male. This tooth, as Kolbe has already explained of submaculata, is curved inward, the tips of the two teeth pointing towards each other. form.

There appear to be several other species which have a tawny and a green

I add a note on another species of Sternotomis, described by Westwood :

\section{Sternotomis virescens.}

Sternotomis virescens Westwood, Arc. Ent. ii. p. 83, no. 1. t. 69. fig. 1 (1845) (Sierra Leone). Sternotomis dubocagei Coquerel, Ann. Soc. Ent. France, p. 186, no. 3. t. 5. fig. 2 (1861) (Angola). Sternotomis aglaura Kolbe, Ent. Zeit. Stett. p. 61. no. 30 (1894) (Uganda ; Cameroons).

The markings of worn specimens are much smaller and greener than those of fresh ones, which are chalky white or but slightly greenish. In the examples from Uganda the markings have sometimes an ochraceous tint.

Sternotomis gama Coquerel, l.c. no. 4. t. 5. fig. 4 (1861) (Angola) is based on a buffish individual of virescens, and St. bohndorfi Waterhouse, Ann. Mag. N. H. (5) xvii. p. 501 (1886) (Niam-Niam), also does not seem to be specifically different from virescens. 


\section{$2 \mathrm{BHL}$ Biodiversity Heritage Library}

Jordan, Karl. 1909. "On Some of the African Longicorns described by Hope and Westwood." Novitates zoologicae : a journal of zoology in connection with the Tring Museum 16, 309-312. https://doi.org/10.5962/bhl.part.21964.

View This Item Online: https://www.biodiversitylibrary.org/item/21989

DOI: https://doi.org/10.5962/bhl.part.21964

Permalink: https://www.biodiversitylibrary.org/partpdf/21964

\section{Holding Institution}

Natural History Museum Library, London

\section{Sponsored by}

Natural History Museum Library, London

\section{Copyright \& Reuse}

Copyright Status: Public domain. The BHL considers that this work is no longer under copyright protection.

This document was created from content at the Biodiversity Heritage Library, the world's largest open access digital library for biodiversity literature and archives. Visit BHL at https://www.biodiversitylibrary.org. 